\title{
Advanced glycosylation end products inhibit the proliferation of bone-marrow stromal cells through activating MAPK pathway
}

Zheng Li ${ }^{1}$, Xiao Wang ${ }^{1 *} \mathbb{D}$, Tian-pei Hong ${ }^{2}$, Hao-jie Wang ${ }^{1}$, Zhan-yi Gao ${ }^{1}$ and Meng Wan ${ }^{1}$

\begin{abstract}
Background: The purpose of present study was to explore the mechanism of nuclear factor-kappa B (NF-KB), phosphatidylinositol 3-kinase (PI3K)/protein kinase B(PKB/Akt) and mitogen-activated protein kinase (MAPK) signaling pathways after intervention of advanced glycosylation end products (AGEs) on rat bone-marrow stromal cells (BMSCs).

Methods: Prepare and identify AGEs. BMSCs were isolated from 16 SD rats and cultured with different concentration of AGEs. Cell viability was detected by cell counting kit-8 (CCK-8). BMSCs were cultured with AGEs $(0.25 \mathrm{mg} / \mathrm{ml})$ for $30 \mathrm{~min}, 12 \mathrm{~h}, 24 \mathrm{~h}, 72 \mathrm{~h}$ and $120 \mathrm{~h}$. In addition, BMSCs were cultured with AGEs, AGEs + JNK inhibitor and AGEs + P38 inhibitor for $24 \mathrm{~h}$ and $48 \mathrm{~h}$, respectively. Western blotting and RT-PCR were used to determine the protein and mRNA expression levels, respectively.
\end{abstract}

Results: Cell viability of BMSCs was significantly correlated with concentration and effect time of AGEs $(P<0.05)$, and the most appropriate concentration was $0.25 \mathrm{mg} / \mathrm{ml}$. AGEs stimulation significantly increased the protein expression levels of NF-KB p65, JNK, p38 $(P<0.05)$, decreased IKB $(P<0.05)$, but had no effect on the protein expression of Akt in BMSCs $(P>0.05)$. At the mRNA level, JNK and p38 inhibitors significantly reduced the levels of NF-KB p65, p38 and $J N K$, increased IKB $(P>0.05)$, but had no effect on Akt in BMSCs $(P>0.05)$. At the protein level, JNK and p38 inhibitors notably decreased the expression of NF-KB p65, p38, p-JNK, P-IKB and JNK $(P<0.001)$, and increased IKB $(P<0.05)$.

Conclusion: Advanced glycosylation end products can inhibit the proliferation of bone-marrow stromal cells through activating MAPK pathway.

Keywords: Advanced glycosylation end products, MAPK pathway, Bone-marrow stromal cells, Proliferation

\section{Background}

Diabetes mellitus and periodontal disease are chronic diseases related to lifestyle with high prevalence worldwide [1]. Epidemiological studies show that diabetes can affect periodontal health [2]. The biological pathogenesis involved is related to the cell and molecular level regulation of hyperglycemia on periodontal tissue [3-5]. In

\footnotetext{
*Correspondence: wang_xiao20@aliyun.com

${ }^{1}$ Department of Stomatology, Peking University Third Hospital, No. 49 Huayuan North Road, Haidian District, Beijing 100191, China

Full list of author information is available at the end of the article
}

2013, the European Periodontal Association (EFP) and the American Periodontal Association (AAP) jointly proposed the possible correlation mechanism between diabetes and periodontitis [6].

Under the condition of hyperglycemia, advanced glycosylation end products (AGEs) and its main signal receptor RAGE interact with each other, which can lead to the abnormal function of immune cells, change the phenotype and function of other important cells in periodontal tissues, and increase the expression of pro-inflammatory cytokines (Interleukin (IL)-6, IL-1 $\beta$, tumor necrosis factor (TNF)- $\alpha$ ) [7]. At the same time, 
hyperglycemia increases the over expression of reactive oxygen species (ROS) and causes oxidative stress [8]. It can directly or indirectly change the quantity and quality of various cytokines through the AGEs/RAGE response axis. In addition, under the condition of hyperglycemia, the proportion regulation of RANKL/ OPG can also lead to inflammation and destruction of periodontal tissue [9]. The change of biomembrane ecosystem of subgingival plaque and the increase of adipocytokine secretion caused by diabetes related obesity and dyslipidemia play a synergistic role, ultimately leading to the loss of metabolism balance of periodontal tissue, which is manifested in the increase of periodontal tissue damage and tissue repair function damage, that is, rapid progress and serious periodontitis [10].

Osteoclasts and osteoblasts are required to participate in the reconstruction of alveolar bone in periodontitis [11]. Therefore, it is important to study the molecular mechanism of alveolar bone destruction, absorption, reconstruction and repair in hyperglycemia to elucidate the biological cause of chronic periodontitis caused by diabetes [12]. AGEs is a nonenzymatic glycosylation product of protein, including collagen and other components, under the condition of chronic hyperglycemia. As a characteristic expression of diabetes, it plays a key role in the pathophysiological process induced by hyperglycemia. Therefore, the purpose of present study was to explore the effect of AGEs on bone-marrow stromal cells (BMSCs) in rats.

\section{Materials and methods \\ Chemicals and antibodies}

Bovine serum albumin (BSA) was obtained from Shanghai Hengyuan Technology Biology Co., Ltd (Shanghai, China). Glucose, Phenylmethylsulfonyl Fluoride (PMSF), and ethylene diamine tetraacetic acid disodium salt (EDTA) were obtained from Beijing solabo Technology Co., Ltd. (Beijing, China). Penicillin and streptomycin were bought from Sangon Biotech Inc. (Shanghai, China). Ethanol (purity $>99 \%$ ) was obtained from Xilong Chemical Co., Ltd. (Guangdong, China). Fetal bovine serum (FBS) was bought from Sangon Biotech, Inc. (Shanghai, China) and Dulbecco's modified eagle medium (DMEM) was purchased from ThermoFisher (MA, USA). CCK-8 kit was obtained from Shanghai Yanjin Biotechnology Co., Ltd. (Shanghai, China). Anti-p-P38, anti-P38, anti-JNK, anti-p-JNK, anti-NF- $\mathrm{kB}$ p65, anti-p-NF- $\mathrm{B}$ p65, anti-ІкB, anti-p-ІкB, anti-AKT and anti-p-AKT antibodies were purchased from Abcam Technology (Cambridge, UK). Anti $\beta$-actin antibody, Goat antirabbit and mouse IgG and mouse anti-goat secondary antibodies were purchased from ZSGB Biotech Co., Ltd. (Beijing, China). Unless specified, all other reagents are obtained from Sigma Chemical Co. (St. Louis, MO, USA).

\section{AGE's preparation}

$2.5 \mathrm{~g} \mathrm{BSA}(50 \mathrm{mg} / \mathrm{ml}), 4.045 \mathrm{~g} \mathrm{D}$-glucose $(500 \mathrm{mmol} / \mathrm{l})$, $0.003 \mathrm{~g}$ penicillin $(100 \mathrm{IU} / \mathrm{ml}), 0.005 \mathrm{~g}$ streptomycin $(100 \mathrm{IU} / \mathrm{ml}), 0.0130642 \mathrm{~g}$ benzenesulfonylfluoro $(1.5 \mathrm{mmol} / \mathrm{l})$ and $0.009306 \mathrm{~g}$ disodium EDTA $(0.5 \mathrm{mmol} / \mathrm{l})$ were dissolved in $50 \mathrm{ml}$ PBS solution with $0.2 \mathrm{mmol} / \mathrm{l}$ and $\mathrm{pH} 7.4)$. After the reagent was fully dissolved, it was filtered by $0.22 \mu \mathrm{M}$ filter membrane and put into sterile test tube. PBS incubated with BSA but without D-glucose was prepared as control under the same conditions. The prepared AGEs were placed in a sterile tube, sealed with a sealing film, and then placed in an incubator at $37^{\circ} \mathrm{C}$ for 90 days to obtain brown products. After incubation, D-glucose which was not combined with BSA was removed by PBS dialysis for $48 \mathrm{~h}$, and then filtered by $0.22 \mu \mathrm{M}$ filter membrane. According to the specific fluorescence characteristics of AGEs, that is, the fluorescence of $440 \mathrm{~nm}$ emission wavelength can be produced under the excitation light of $370 \mathrm{~nm}$ wavelength, the fluorescence values of incubated AGEs-BSA and the control were determined by FLX-800 fluorescence spectrophotometer. Finally, put the prepared ages into the refrigerator at $-20{ }^{\circ} \mathrm{C}$ until use.

Isolation and culture of bone-marrow stromal cells (BMSCs) The animal experiments were approved by the Institutional Ethical Committee of Peking University Third Hospital. A total of 16 Sprague-Dawley (SD) male 
rats, aged 4 months, were purchased from the Experimental Animal Centre of Peking University Third Hospital and maintained under standard living conditions (room temperature of $22 \pm 2{ }^{\circ} \mathrm{C}, 50-60 \%$ relative humidity, and $12 \mathrm{~h}$ dark/light cycle). One week after adaptive feeding, SD rats were anesthetized with $50 \mathrm{mg} / \mathrm{kg}$ pentobarbital sodium and soaked in $75 \%$ ethanol for $5 \mathrm{~min}$. The femur was separated under aseptic condition, the metaphysis was cut off, and the marrow cavity was washed several times with culture medium. The cell suspension was transferred into the test tube and filtered with 100 mesh and 200 mesh stainless steel filters to obtain the single cell suspension. Two drops of red blood cell (RBC) lysate was added and the cells were collected by centrifugation at $1000 \mathrm{rmp} / \mathrm{min}$ for $10 \mathrm{~min}$. DMEM medium containing 15\% FBS was used to cultured cells. The cells were adjusted to $10^{7}$ cells $/ \mathrm{ml}$, and cultured in $37{ }^{\circ} \mathrm{C}$ and $5 \% \mathrm{CO}_{2}$ incubator. When the suspension cells were removed, the adherent cells were BMSCs. L-02 cells were maintained in a humidified incubator with a $5 \%$ $\mathrm{CO}_{2} / 95 \%$ air atmosphere at $37{ }^{\circ} \mathrm{C}$ and passaged daily by trypsin-EDTA digestion (Solarbio Co., Beijing, China).

\section{Cell counting kit-8 (CCK-8) assay}

BMSCs in logarithmic growth phase inoculated in 96-well plate $\left(5 \times 10^{5}\right.$ per well). After attachment to the plates, BMSCs were cultured with 0.125, 0.25, 0.5, 1.0 and $2.0 \mathrm{mM}$ AGEs. At $24 \mathrm{~h}, 48 \mathrm{~h}$ and $72 \mathrm{~h}, 10 \mu \mathrm{l} \mathrm{CCK-8}$ reagent was added to each well, and the cells were continued to culture for $1 \mathrm{~h}$. The optical density (OD) was detected at $490 \mathrm{~nm}$ by a microplate reader (BioRad, Inc., Hercules, CA, USA), and the IC50 value was calculated.

\section{Grouping}

BMSCs in logarithmic growth phase inoculated in culture flask with $25 \mathrm{~cm}^{2}$. To explore the mechanism of AGEs in the proliferation of BMSCs, BMSCs were divided into 12 groups. Cells were cultured with PBS or $0.25 \mathrm{mM}$ for $30 \mathrm{~min}, 12 \mathrm{~h}, 1$ day, 3 days and 5 days, respectively. Furthermore, BMSCs were divided into 12 groups. Cells were cultured with PBS, $0.25 \mathrm{mM}$ AGEs, JNK inhibitor (SP600125), $0.25 \mathrm{mM}$ AGEs + JNK inhibitor, P38 inhibitor (SB203580), $0.25 \mathrm{mM}$ AGEs + P38 inhibitor for $24 \mathrm{~h}$ or $48 \mathrm{~h}$. After
Table 1 Primer sequences

\begin{tabular}{|c|c|c|c|}
\hline Genes & $\begin{array}{l}\text { Forward primer } \\
\left(5^{\prime}-3^{\prime}\right)\end{array}$ & $\begin{array}{l}\text { Reverse primer } \\
\left(5^{\prime}-3^{\prime}\right)\end{array}$ & length (bp) \\
\hline NF-kBp65 & $\begin{array}{l}\text { CGGATTGAAGAA } \\
\text { AAACG }\end{array}$ & $\begin{array}{l}\text { TTGAAAAGGCAT } \\
\text { AGGGC }\end{array}$ & $169 \mathrm{bp}$ \\
\hline JNK & $\begin{array}{l}\text { TTAGATGAAAGG } \\
\text { GAGCA }\end{array}$ & $\begin{array}{l}\text { TGACGCCATTCT } \\
\text { TAGTT }\end{array}$ & $91 \mathrm{bp}$ \\
\hline P38 & $\begin{array}{l}\text { CAGATGCCGAAGATG } \\
\text { AAC }\end{array}$ & $\begin{array}{l}\text { CCTCTTATCCGAGTC } \\
\text { CAA }\end{array}$ & $99 \mathrm{bp}$ \\
\hline Akt & $\begin{array}{l}\text { CACAGGTCGCTACTA } \\
\text { TGCC }\end{array}$ & $\begin{array}{l}\text { GGTCGTGGGTCTGGA } \\
\text { ATG }\end{array}$ & $152 b p$ \\
\hline $\mid \mathrm{KB}$ & $\begin{array}{l}\text { CTGCGTGATGAAGAT } \\
\text { TGGA }\end{array}$ & $\begin{array}{l}\text { GCATCCCTGAGCAGT } \\
\text { TGG }\end{array}$ & $116 \mathrm{bp}$ \\
\hline$\beta$-actin & $\begin{array}{l}\text { GGCACCACACCT } \\
\text { TCTAC }\end{array}$ & $\begin{array}{l}\text { CTGGGTCATCTT } \\
\text { TTCAC }\end{array}$ & $107 \mathrm{bp}$ \\
\hline
\end{tabular}

incubation, cells in each group were collected for subsequent experiments.

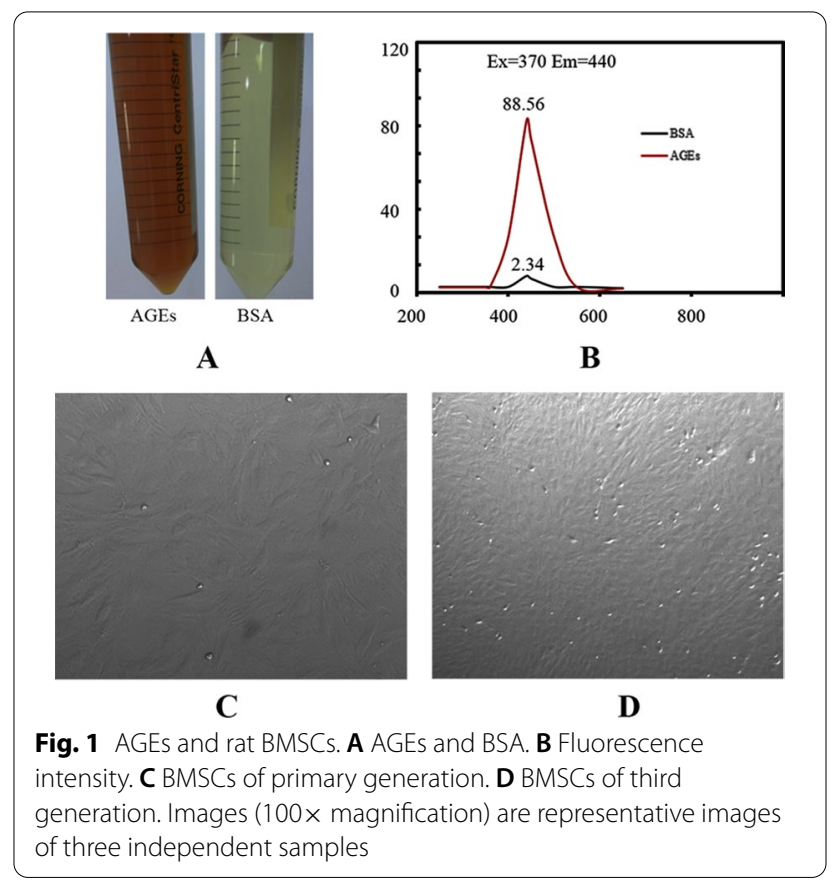




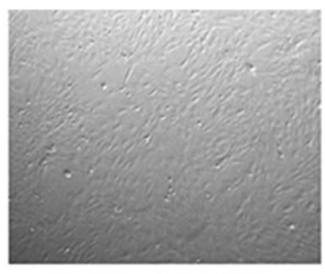

0.125 mM AGEs

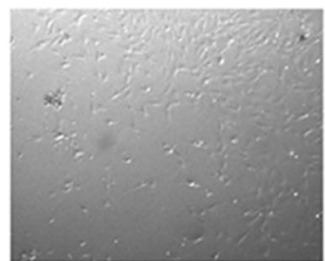

1.0 mM AGEs

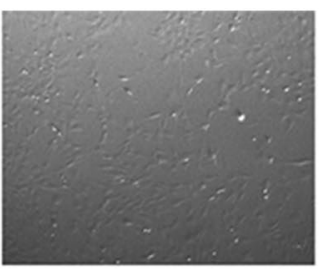

0.25 mM AGEs

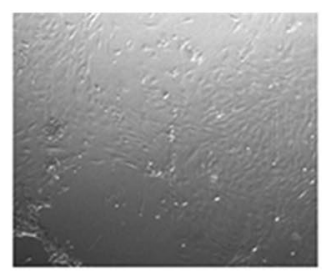

0.5 mM AGEs

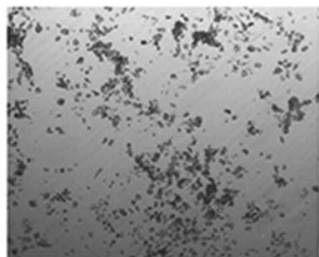

$2.0 \mathrm{mM}$ AGEs

A

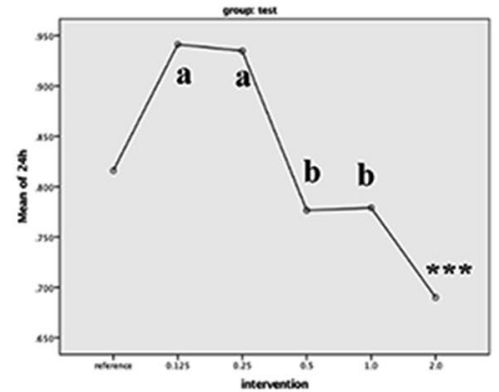

B

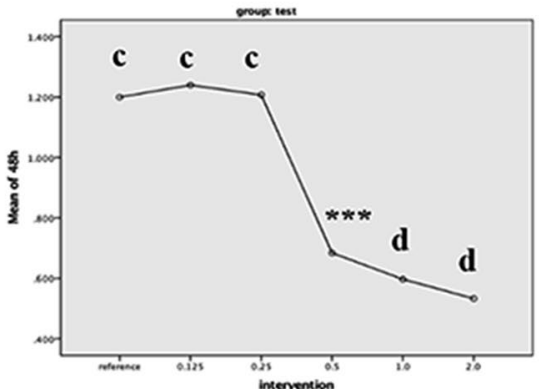

C

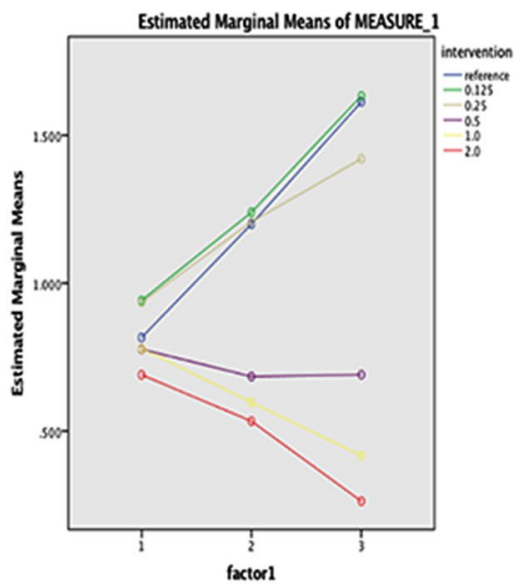

E

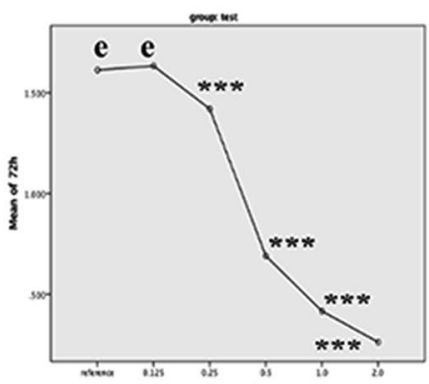

D

Fig. 2 Effect of AGEs on cell viability of BMSCs. A Effects of different concentrations of AGEs on the differentiation of BMSCs. B Effects of different concentrations of AGEs on the differentiation of BMSCs for $24 \mathrm{~h}$. C Effects of different concentrations of AGEs on the differentiation of BMSCs for $48 \mathrm{~h}$. D Effects of different concentrations of AGEs on the differentiation of BMSCs for $72 \mathrm{~h}$. $\mathbf{E}$ Effects of action time and concentration of AGEs on cell vitalities of BMSCs. Images (100x magnification) are representative images of three independent samples. Data are expressed as means \pm SD. ${ }^{* * *} P<0.001 ;{ }^{a}, \mathrm{~b}, \mathrm{c}, \mathrm{d}, \mathrm{e}, \mathrm{P}<0.001$ vs. control group (ANOVA, $F=20.8-157.7$ )

\section{RT-PCR}

Total RNA from BMSCs was obtained using a total RNA isolation kit (Tiangen Biotech Co., Ltd., Beijing, China) according to the directions. Total RNA was reversibly transcribed to cDNA using cDNA synthesis kit (TIANScript cDNA; Tiangen Biotech) according to the specification. RT-PCR was carried out by MJ PTC-200 PCR system (Bio-Rad) and RT-PCR kit (Aidlab Biotech Co., Ltd., Beijing, China). Specific primers (Table 1) are shown in Table 1. mRNA was measured by real-time PCR. Relative gene expression levels were calculated using the $2^{-\Delta \Delta} \mathrm{C}$ method (with $\beta$-actin used as the reference gene) and normalized as indicated.

\section{Western blotting}

The total protein of BMSCs were homogenized in cold RIPA buffer (Beyotime Institute of Biotechnology, Shanghai, China). Supernatants were collected after 


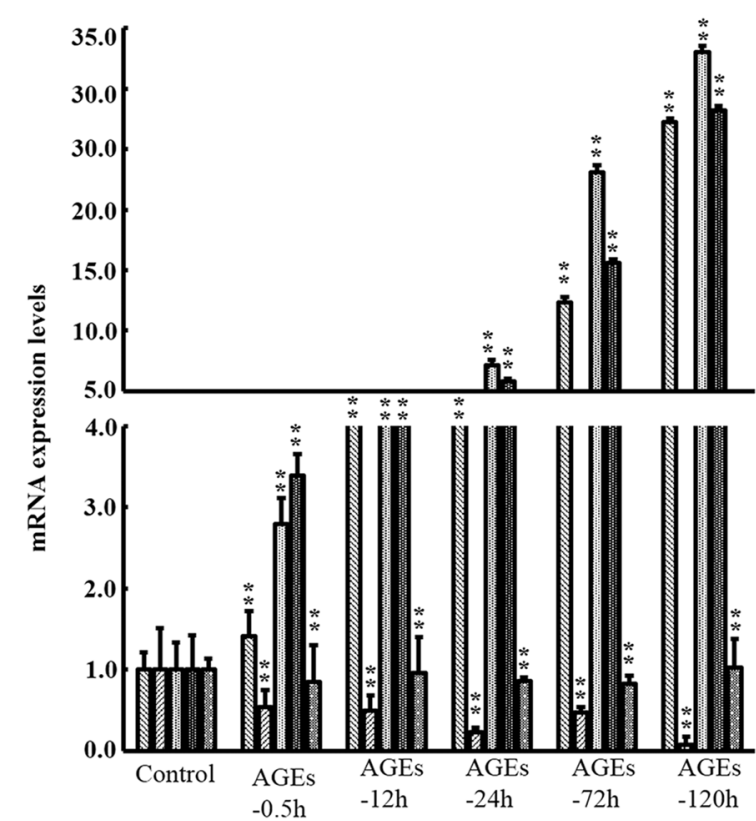

Fig. 3 Effect of AGEs on mRNA expression levels of factors in MAPK signaling pathway. Data are expressed as means \pm SD $(n=3)$. ***P $<0.001$ vs. control group

centrifuging at $12,000 \times g$ for $20 \mathrm{~min}$ at $4{ }^{\circ} \mathrm{C}$. Protein concentration was measured using a BCA protein concentration assay kit (Beyotime Institute of Biotechnology, Shanghai, China). Protein were separated by SDS-PAGE and transferred to nitrocellulose membrane. The membrane was blocked for $1 \mathrm{~h}$ at room temperature with nonfat dried milk or BSA. Membranes were incubated with primary antibodies overnight at $4{ }^{\circ} \mathrm{C}$, followed by incubating secondary antibodies for $1 \mathrm{~h}$ at room temperature. Then, they were exposed to ECL Western Blotting Substract reagent (Tsea biotech Co., Shanghai, China). Molecular Imager Chemi Doc XRS (BIO-RAD Co., California, USA) and JS-780 automatic gel imaging analysis systems were used for blotting and quantitative analysis. $\beta$-actin was used as the internal control.

\section{Statistical analysis}

SPSS22.0 software (International Business Machines, corp., Armonk, NY, USA) was used for statistical analysis. The measurement data were expressed as means \pm standard deviation (SD) and tested for normal distribution. The difference between groups was compared by independent sample $t$ test. One-way analysis of variance
(ANOVA) was used to compare the difference among the groups. The data of repeated measurement were analyzed by general linear model (GLM). $P<0.05$ was considered statistically significant.

\section{Results}

Preparation of AGEs and rat BMSCs

The fluorescence intensity of AGEs reagent was 88.56 $\mathrm{U} / \mathrm{mg}$ and that of BSA was $2.34 \mathrm{U} / \mathrm{mg}$ (Fig. 1A, B). The results showed that it was consistent with the spontaneous fluorescence characteristics of AGEs. Furthermore, as shown in Fig. 1C, D, BMSCs were scattered at the bottom of the dish. Some cells adhered to the wall with different sizes and oval clusters. With the increase of time, the cells became long fusiform, many colonies were formed and arranged radially.

\section{Effect of AGEs on cell viability of BMSCs}

BMSCs under the effect of AGEs at different concentrations after $48 \mathrm{~h}$ of culture are shown in Fig. $2 \mathrm{~A}$. It suggested that the proliferation of the cells was significantly inhibited by AGEs, and the higher the concentration of AGEs, the more obvious the inhibition. The effects of different AGEs (2, 1, 0.5, 0.25 and $0.125 \mathrm{mM}$ ) on proliferation of BMSCs in 24, 48 and $72 \mathrm{~h}$ are shown in Fig. 2B, C and D. At each time, the cell viability was decreased with the increase concentration of AGEs with significant differences between the groups $(P<0.05)$. Besides, GLM analysis showed that the cell viability was significantly correlated with concentration, time and their interaction of AGEs $(P<0.05)$, and when the concentration was more than $0.5 \mathrm{mM}$, the cell viability was significantly decreased with effect time (Fig. 2E).

\section{Effect of AGEs on MAPK signaling pathway}

BMSCs were treated with $0.25 \mathrm{mM}$ AGEs for $30 \mathrm{~min}$, $12 \mathrm{~h}, 1$ day, 3 days and 5 days, respectively. The mRNA expression levels are shown in Fig. 3. With the prolongation of the action time, AGEs notably increased the mRNA expression levels of NF-kB p65, JNK and P38, and decreased the mRNA expression levels of IKB $(P<0.05)$. However, there was no significantly difference in Akt mRNA expression level $(P>0.05)$. 


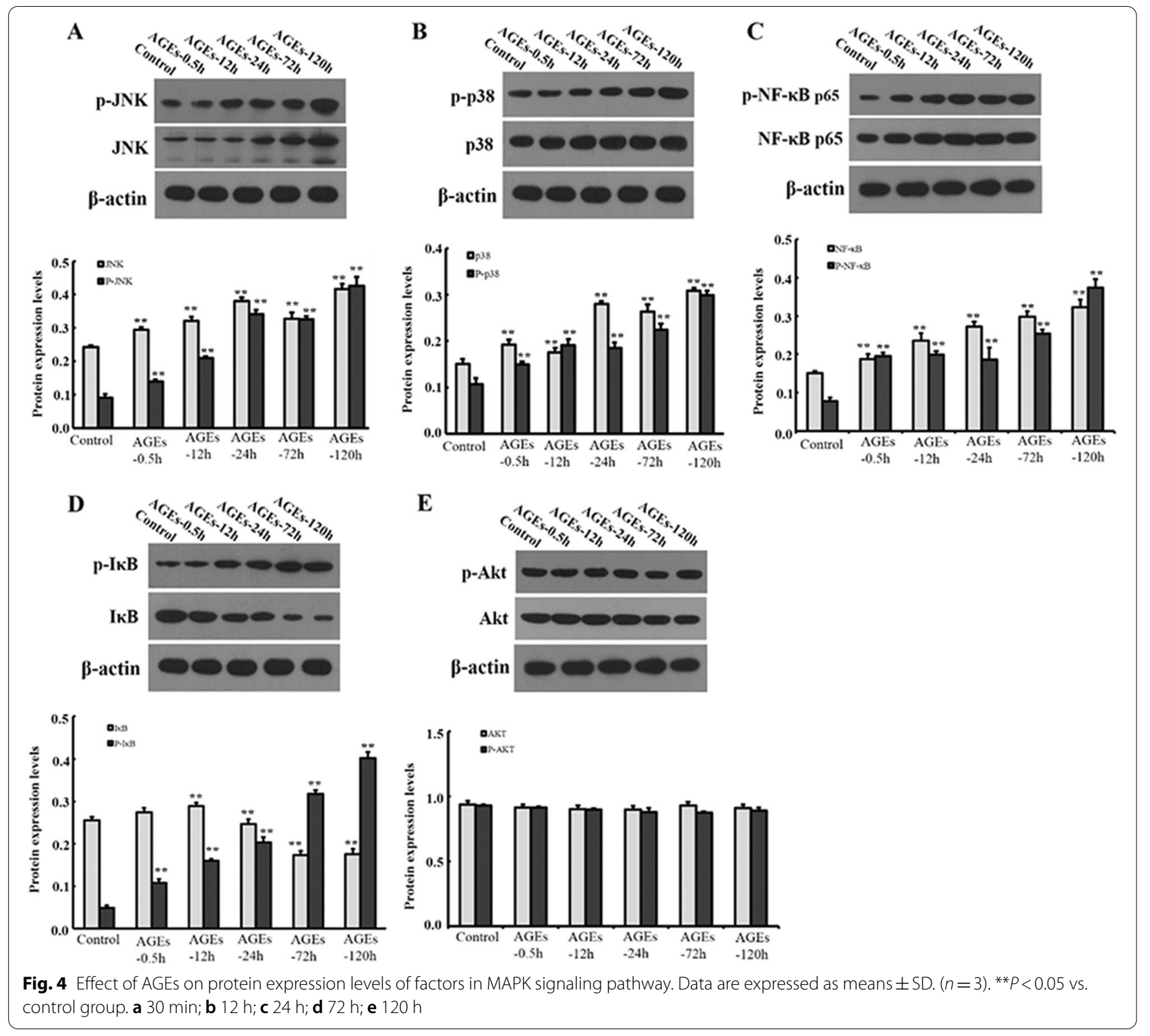

Moreover, we also detected the protein expression levels of related factors in MAPK signaling pathway (Fig. 4). With the prolongation of action time, AGEs notably increased the protein expression levels of NF-kB p65, p-NF-kB p65, JNK, p-JNK, p-P38, P38 and $\mathrm{p}-\mathrm{I} \kappa \mathrm{B}$, but decreased the expression of ІкB $(P<0.05)$. However, there was no significantly difference in protein expression level of Akt and $\mathrm{p}$-Akt $(P>0.05)$.
The effect of JNK and P38 signaling pathway in the proliferation of BMSCs induced by AGEs

BMSCs were induced by JNK inhibitor (SP600125) and P38 inhibitor (SB203580) for $30 \mathrm{~min}$, then $0.25 \mathrm{mg} / \mathrm{ml}$ AGEs was added to BMSCs for $24 \mathrm{~h}$ and $48 \mathrm{~h}$. As shown in Fig. 5, the mRNA expression levels of NF- $\mathrm{kB}$ p65, P38 and JNK were significantly decreased when JNK inhibitor and P38 inhibitor were added $(P<0.05)$. However, there was no significantly difference in Akt mRNA expression level when JNK inhibitor and P38 inhibitor were added $(P>0.05)$. In addition, we also evaluated the protein expression levels. As shown in Figs. 6 and 7, the protein expression levels of NF- $\mathrm{kB}$ p65, p38, JNK with 


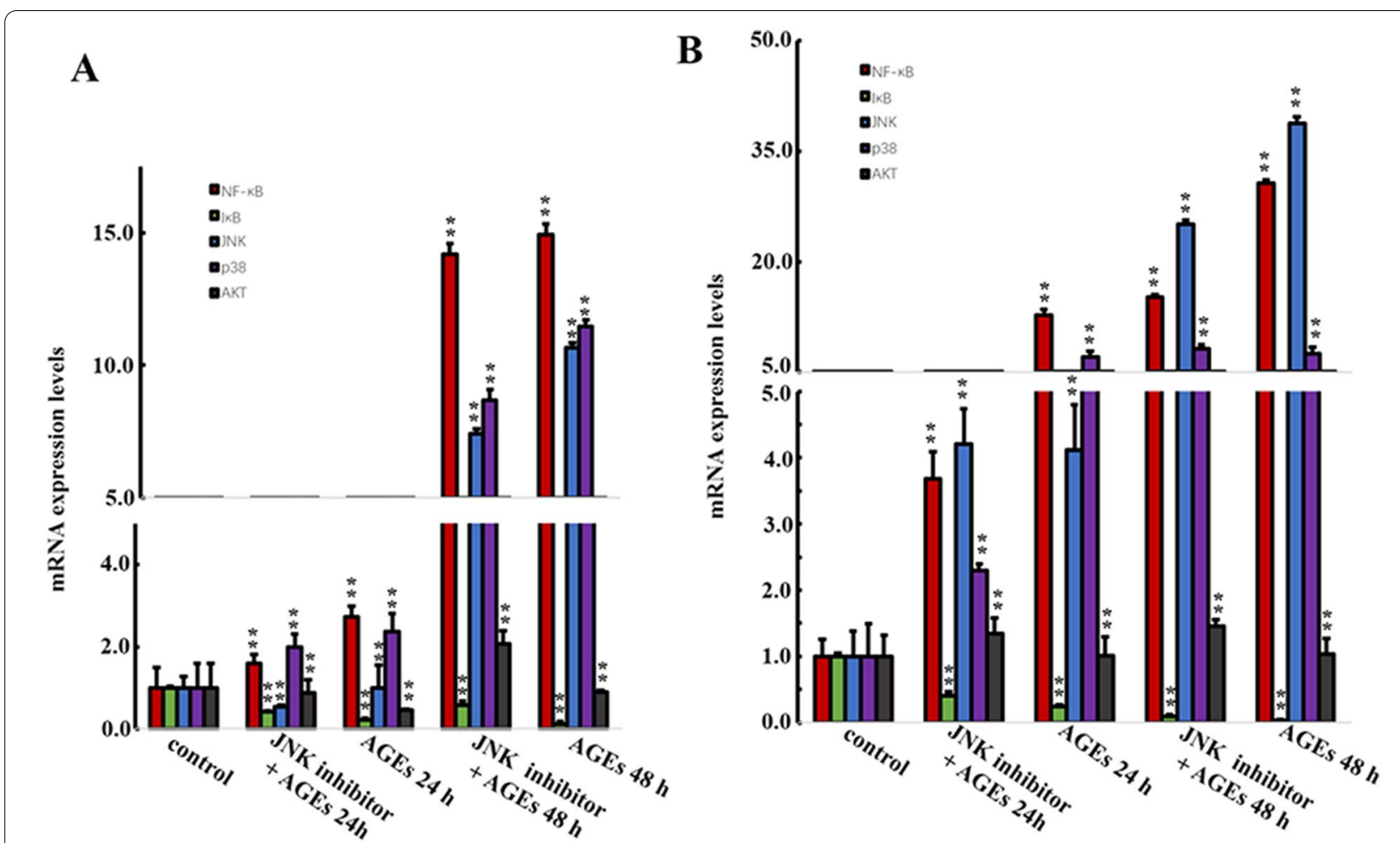

Fig. 5 Effect of JNK and P38 inhibitors on AGEs in mRNA expression levels of factors in MAPK signaling pathway. Data are expressed as means \pm SD $(n=3) .{ }^{* *} P<0.05$ vs. control group

phosphorylation and non-phosphorylation and IкB phosphorylation in BMSCs were significantly decreased, while I $\kappa$ B non-phosphorylation was significantly increased when JNK inhibitor and P38 inhibitor were added $(P<0.05)$.

\section{Discussion}

AGEs, as glycosylated products of protein and collagen in hyperglycemia, mediate their biological effects by binding to their receptor of RAGE [13]. RAGE is a kind of membrane protein, which can be divided into extracellular domain, transmembrane domain and intracellular segment, and belongs to immunoglobulin superfamily. RAGE is expressed on many cell surfaces, such as monocytes, megaphiles, endothelial cells, smooth muscle cells and fibroblasts. When cells are activated or stressed (hyperglycemia, inflammation), the expression of RAGE is significantly increased. AGEs and RAGE can trigger a variety of signal transduction pathways, such as NADPH oxidase ROS pathway, phosphatidylinositol 3-kinase (PI3-K) - protein kinase B (PKB/Akt) pathway and mitogen-activated protein kinase (MAPK) pathway [14]. It involves extracellular signal regulatory enzymes, including ERK, p38, JNK and other upstream factors, further activating nuclear factor- $\mathrm{kB}(\mathrm{NF}-\mathrm{\kappa B})$ cascade to play a biological role [15]. The purpose of this study was to detect the effect of AGEs on proliferation of BMSCs, and to analyze the role of PI3K/Akt and MAPK signaling pathway in AGEs-RAGE axis.

CCK-8 test showed that there was a dose and time correlation between AGEs and the activity of BMSCs. With the increase of concentration of AGEs, the cell activity gradually decreased. When the dose exceeded the critical dose of $0.5 \mathrm{mM}$, the cell activity also decreased significantly with the increase of action time. Therefore, AGEs were selected as the best dosage of $0.25 \mathrm{mM}$.

NF- $\mathrm{kB}$ is a protein family composed of a group of transcription factors with similar structure, and it is an important signaling molecule in intracellular signal transmission. The classical activation mechanism of $N F-\kappa B$ is as follows [16]. In the resting state, NF- $k B$ and 
A
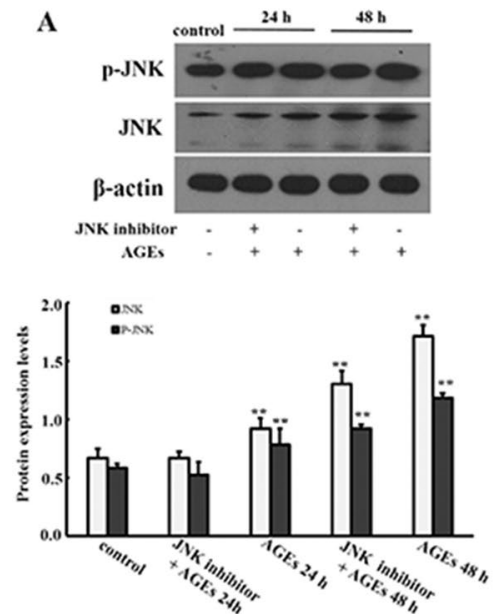

D
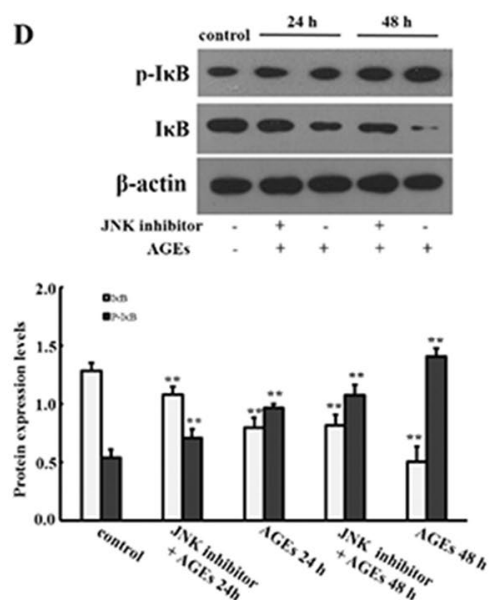
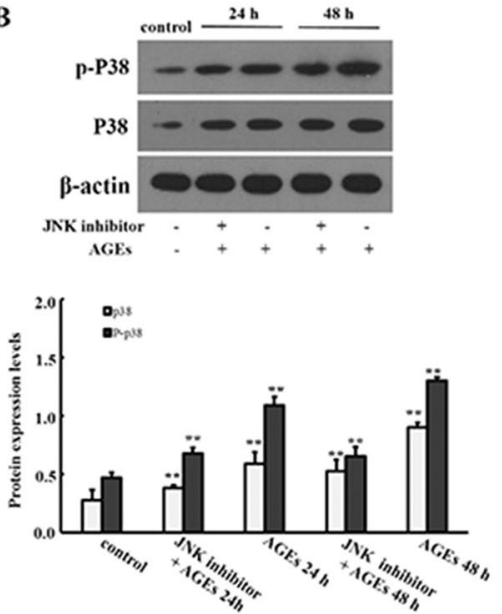

$\mathbf{E}$
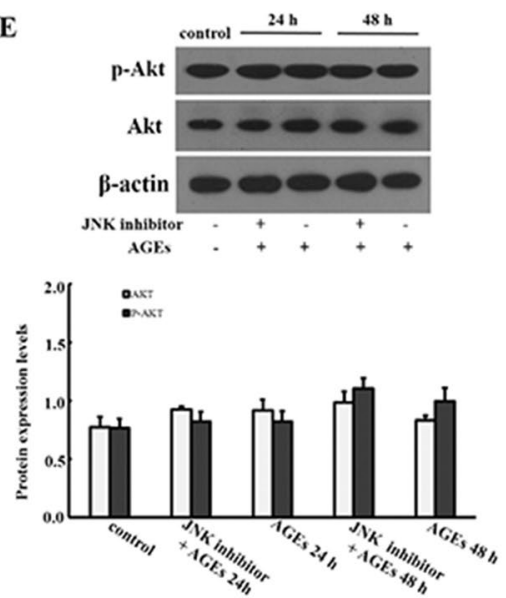

C
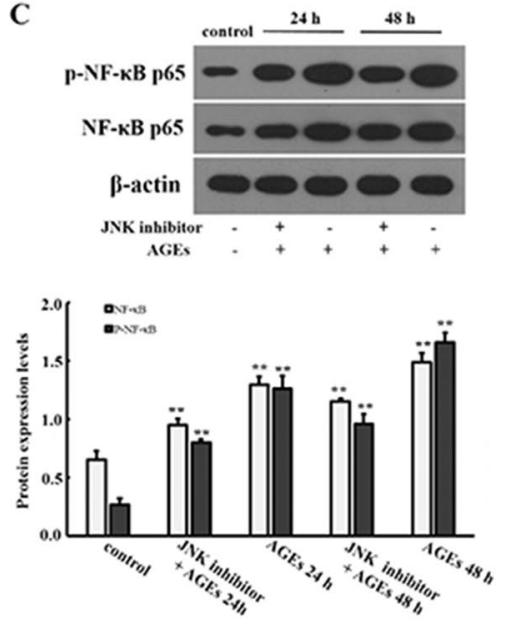

Fig. 6 Effect of JNK inhibitor on AGEs in protein expression levels of factors in MAPK signaling pathway. Data are expressed as means \pm SD ( $n=3$ ). ${ }^{*} P<0.001$ vs. control group

its inhibitor IKB exist in the cytoplasm in the form of trimer, and the nuclear localization signal is masked and inactive. After stimulated by the external environment, the trimer dissociates and releases NF- $\mathrm{kB}$, whose nuclear localization signal is exposed, which leads NF- $\mathrm{kB}$ into the nucleus and specifically combines with the corresponding target sequence. It starts regulating the transcription of multiple genes, and plays an important role in the immune response and inflammatory response. This study confirms that AGEs $(0.25 \mathrm{mM})$ can promote the activation of NF-kB in BMSCs. The protein expression levels of JNK, p-JNK, p38 and p-p38 in upstream factors were increased, but the protein expression of $\mathrm{p}$-Akt and Akt had no statistical difference, suggesting that JNK and P38 signaling pathways but not PI3K Akt pathway were involved in the effect of AGEs on BMSCs. In addition, during the proliferation of NF- $\mathrm{kB}$, the increased expression of $\mathrm{p}$-ІкB protein was accompanied by the decreased expression of IкB. The activation mechanism of NF- $\mathrm{kB}$ mediated by AGEs-RAGE was verified. Under the stimulation of AGEs, $\mathrm{p}-\mathrm{I} \kappa \mathrm{B}, \mathrm{NF}-\mathrm{\kappa} \mathrm{B}$ trimer degraded and released NF- $\mathrm{kB}$, which showed that NF- $\mathrm{kB}$ pathway was activated and played a biological role.

To verify the hypothesis that JNK and P38 signal pathways are involved in AGEs regulation, JNK and p38 signal pathway inhibitors were added, respectively. The results showed that AGEs had a significant effect on BMSCs with stem cell properties and multi-directional differentiation potential. After blocking the pathway, the originally increased mRNA and protein levels of NF-kB p65, p38, JNK were decreased in BMSCs induced by AGEs. In addition, the increased protein levels of $\mathrm{p}-\mathrm{NF}-\mathrm{kB}$ p65, p-p38, p-JNK and p-P38 were also decreased. It is 


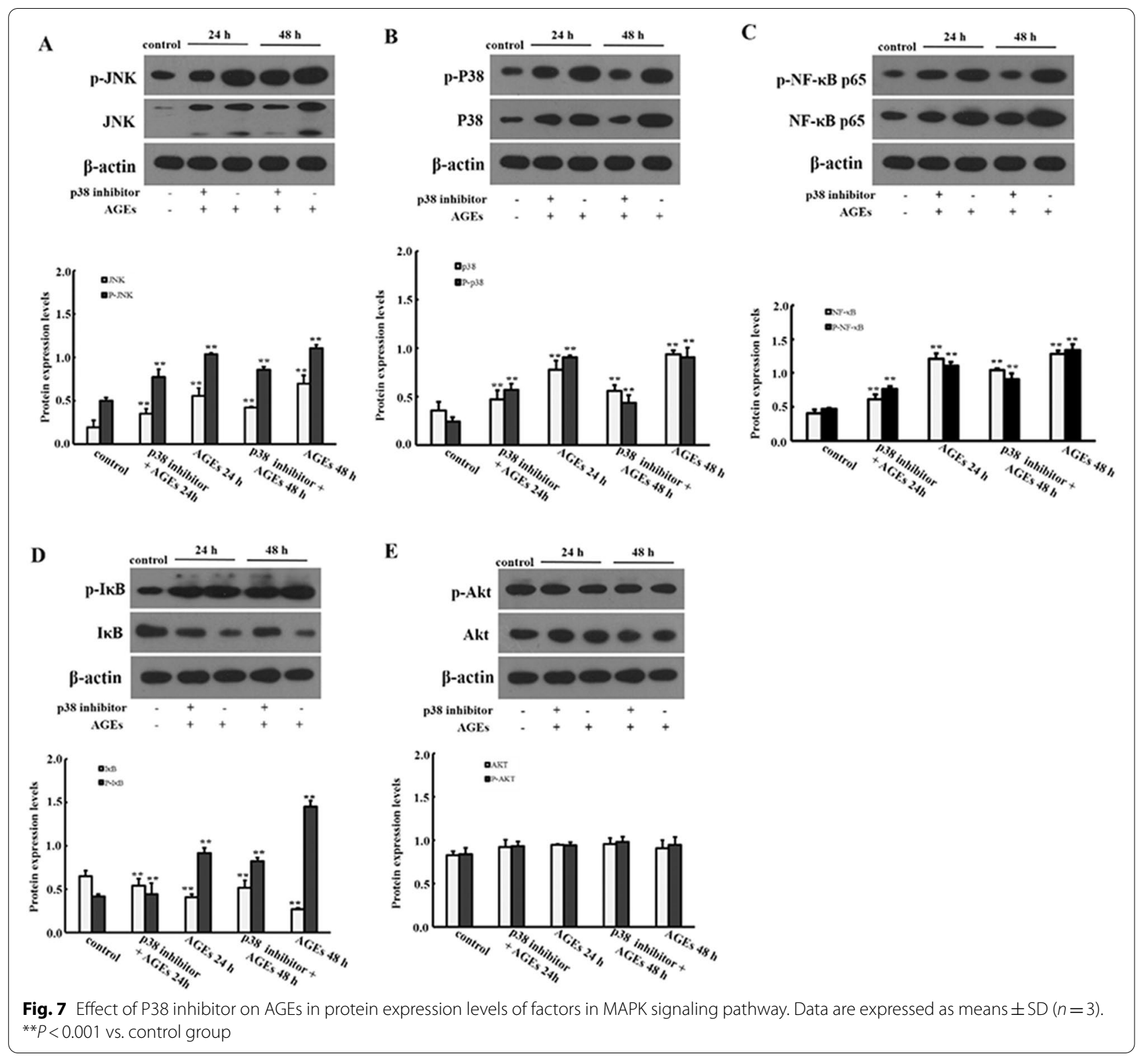


concluded that JNK and p38 signaling pathways play a synergistic role in the differentiation of BMSCs by AGEs.

There are some disadvantages in present study. First, there is no evidence in vivo about the effect and mechanism of AGEs on BMSCs. Furthermore, only CCK-8 method is used to detect cell proliferation, and there is no more method to detect cell proliferation.

\section{Conclusion}

In conclusion, in this study, BMSCs closely related to alveolar bone resorption in periodontal diseases were studied. It was confirmed that AGEs could inhibit BMSCs proliferation and NF- $\mathrm{KB}$ expression. This process was affected by JNK and p38 signal regulation in MAPK pathway, and had nothing to do with PI3K/Akt signal pathway. In the future, we can further analyze the effects of AGEs-RAGE axis on the biological effects of BMSCs, such as the detection of some active cytokines and the expression of some osteogenic genes. In addition, to fully understand the effect of hyperglycemia on periodontal soft and hard tissues, we can continue to explore the effect of AGEs on monocytes, osteoblasts, osteoclasts and potential interaction of cells.

\begin{abstract}
Abbreviations
AGEs: Advanced glycosylation end products; BMSCs: Bone-marrow stromal cells; CCK-8: Cell counting kit-8; EFP: European Periodontal Association; AAP: American Periodontal Association; ROS: Reactive oxygen species; BSA: Bovine serum albumin; PMSF: Phenylmethylsulfonyl Fluoride; EDTA: Ethylene diamine tetraacetic acid; FBS: Fetal bovine serum; DMEM: Dulbecco's modified eagle medium; SD: Sprague-Dawley; RBC: Red blood cell; OD: Optical density; SD: Standard deviation; ANOVA: Analysis of variance; GLM: General linear model; PI3-K: Phosphatidylinositol 3-kinase; PKB/Akt: Protein kinase B; pathway MAPK: Mitogen-activated protein kinase; NF-kB: Nuclear factor-kB.
\end{abstract}

\section{Acknowledgements}

We thank the Special Fund for the Study of the Relationship between Oral Diseases and Systemic Diseases of the Chinese Stomatological Association.

\section{Authors' contributions}

$\mathrm{ZL}$ is responsible for the study concepts and design, statistical analysis, manuscript preparation, editing and review; XW is responsible for the guarantor of integrity of the entire study; TPH is responsible for the definition of intellectual content; $\mathrm{HW}$ is responsible for the literature research, data acquisition; ZYG is responsible for the data analysis; MW is responsible for the experimental studies. All authors read and approved the final manuscript.

\section{Funding}

This study was funded by the Special Fund for the Study of the Relationship between Oral Diseases and Systemic Diseases of the Chinese Stomatological Association (CSA-Y2015-08).

\section{Availability of data and materials}

Not applicable.

\section{Declarations}

\section{Ethics approval and consent to participate}

The animal experiments were approved by the Institutional Ethical Committee of Peking University Third Hospital. Sprague-Dawley (SD) rats, aged 4 months, were purchased from the Experimental Animal Centre of Peking University Third Hospital and maintained under standard living conditions.

\section{Consent for publication}

Not applicable.

\section{Competing interests}

There are no potential conflicts of interest to disclose.

\section{Author details}

${ }^{1}$ Department of Stomatology, Peking University Third Hospital, No. 49 Huayuan North Road, Haidian District, Beijing 100191, China. ${ }^{2}$ Department of Endocrinology, Peking University Third Hospital, Beijing 100191, China.

Received: 13 April 2021 Accepted: 22 July 2021

Published online: 18 August 2021

\section{References}

1. Petersen PE, Ogawa H. The global burden of periodontal disease: towards integration with chronic disease prevention and control. Periodontol. 2012;60:15-39. https://doi.org/10.1111/j.1600-0757.2011. 00425.x.

2. Papapanou PN. Periodontal disease: epidemiology. Ann Periodontol. 1996;1:11-36. https://doi.org/10.1902/annals.1996.1.1.1.

3. Khader YS, Dauod AS, El-Qaderi SS, Alkafajei A, Batayha WQ. Periodontal status of diabetics compared with nondiabetics: a meta-analysis. J Diabetes Complications. 2006;20:59-68. https://doi.org/10.1016/j.jdiacomp. 2005.05.006.

4. Li Z, Sha YQ, Zhang BX, Zhu L, Kang J. The effect of community periodontal health care intervention on periodontal health and blood glucose metabolism in patients with type 2 diabetes. J Peking Univ: Medical Edition. 2011;43:285-9. https://doi.org/CNKl:11-4691/R.20110301.1337.002.

5. Matthews DC. The relationship between diabetes and periodontal disease. J Can Dent Assoc. 2002;68:161-4.

6. Taylor JJ, Preshaw PM, Lalla E. A review of the evidence for pathogenic mechanisms that may link periodontitis and diabetes. J Clin Periodontol. 2013;40:S113-34. https://doi.org/10.1902/jop.2013.134005.

7. Volpe CMO, Villar-Delfino PH, Dos Anjos PMF, Nogueira-Machado JA. Cellular death, reactive oxygen species (ROS) and diabetic complications. Cell Death Dis. 2018;9:119. https://doi.org/10.1038/ s41419-017-0135-z.

8. Russo I, Frangogiannis NG. Diabetes-associated cardiac fibrosis: cellular effectors, molecular mechanisms and therapeutic opportunities. J Mol Cell Cardiol. 2016;90:84-93. https://doi.org/10.1016/j.yjmcc.2015.12. 011.

9. Elenkova M, Tipton DA, Karydis A, Stein SH. Vitamin D attenuates human gingival fibroblast inflammatory cytokine production following advanced glycation end product interaction with receptors for AGE. J Periodontal Res. 2019;54:154-63. https://doi.org/10.1111/jre.12613.

10. Taiyeb-Ali TB, Cheta Raman RP, Vaithilingam RD. Relationship between periodontal disease and diabetes mellitus: An Asian perspective. Periodontol. 2000;2011(56):258-68. https://doi.org/10.1111/j.1600-0757. 2010.00370.x.

11. Jiang N, Guo W, Chen M, Zheng Y, Zhou J, Kim SG, et al. Periodontal ligament and alveolar bone in health and adaptation: tooth movement. Front Oral Biol. 2016;18:1-8. https://doi.org/10.1159/000351894.

12. Shen Y, Guo S, Chen G, Ding Y, Wu Y, Tian W. Hyperglycemia induces osteoclastogenesis and bone destruction through the activation of Ca2+/calmodulin-dependent protein kinase II. Calcif Tissue Int. 2019;104:390-401. https://doi.org/10.1007/s00223-018-0499-9. 
13. Sahajpal NS, Goel RK, Chaubey A, Aurora R, Jain SK. Pathological perturbations in diabetic retinopathy: hyperglycemia, AGEs, oxidative stress and inflammatory pathways. Curr Protein Pept Sci. 2019;20:92-110. https://doi.org/10.2174/1389203719666180928123449.

14. Chaves MM, Costa DC, de Oliveira BF, Rocha MI, Nogueira-Machado JA. Role PKA and p38 MAPK on ROS production in neutrophil age-related: lack of IL-10 effect in older subjects. Mech Ageing Dev. 2009;130:58891. https://doi.org/10.1016/j.mad.2009.07.001.

15. Southerlan JH, Taylor GW, Moss K, Beck JD, Offenbacher S. Commonality in chronic inflammatory diseases: periodontitis, disbetes, and coronary artery disease. Periodontol. 2000;2006(40):130-43. https://doi. org/10.1111/j.1600-0757.2005.00138.x.
16. Bierhaus A, Schiekofer S, Schwaninger M, Andrassy M, Humpert PM, Chen $J$, et al. Diabetes-associated sustained activation of the teanscription factor nuclearfactor-kappaB. Diabetes. 2001;50:2792-808. https://doi.org/10. 2337/diabetes.50.12.2792

\section{Publisher's Note}

Springer Nature remains neutral with regard to jurisdictional claims in published maps and institutional affiliations.
Ready to submit your research? Choose BMC and benefit from:

- fast, convenient online submission

- thorough peer review by experienced researchers in your field

- rapid publication on acceptance

- support for research data, including large and complex data types

- gold Open Access which fosters wider collaboration and increased citations

- maximum visibility for your research: over 100M website views per year

At BMC, research is always in progress.

Learn more biomedcentral.com/submissions 